\title{
STABILISASI TANAH LEMPUNG DENGAN BUBUK ARANG KAYU TERHADAP KUAT GESER
}

\author{
Ilham Akbar Wasaraka \\ Program Studi Teknik Sipil Universitas Muhammadiyah Sorong \\ Jalan Pendidikan No 27 Kota Sorong, Propinsi Papua Barat \\ Email : dwipurwanti700@gmail.com
}

\begin{abstract}
ABSTRAK
Tanah merupakan dasar pondasi dari suatu bangunan agar bangunan tersebut dapat berdiri dengan kokoh dan dapat digunakan secara aman. Tanah yang baik tidak memerlukan perlakuan khusus pada saat tanah tersebut digunakan sebagai pondasi suatu bangunan, namun tidak semua tanah memiliki sifat tanah yang baik yang mengakibatkan apabila dibangun suatu bangunan gedung, rumah, jalan, dan sebagainya bisa mengakibatkan terjadinya kerusakan pada konstruksi di atasnya. Kondisi tanah yang kurang baik terdapat di jalan SP 4 kelurahan Makbalim Distrik Mayamuk Kabupaten Sorong. Hal ini dapat terlihat dari kondisi tanah yang keras saat kemarau dan becek pada musim hujan serta jalan yang mudah rusak seperti yang dibangun di daerah tersebut dengan kurang baik atau mudah mengalami kerusakan seperti jalan berlubang, bergelombang, dan adapun bahu jalan yang longsor. Tujuan penelitian ini adalah untuk menganalisa karakteristik dari tanah asli Jalan SP 4 kelurahan Makbalim Distrik Mayamuk Kabupaten Sorong dan untuk menganalisa pengaruh pencampuran arang kayu pada tanah lempung terhadap kuat geser tanah.
\end{abstract}

Kata Kunci : stabilisasi tanah; kuat geser ; kota sorong

\section{PENDAHULUAN}

\section{Latar Belakang}

Tanah didefinisikan sebagai material yang terdiri dari agregat (butiran) mineral-mineral padat yang tidak tersementasi (terikat secara kimia) satu sama lain dan dari bahan-bahan organik yang telah melapuk (yang berpartikel padat) disertai dengan zat cair dan gas yang mengisi ruang-ruang kosong diantara partikel-partikel padat tersebut.

Tanah merupakan dasar pondasi suatu bangunan agar bangunan tersebut dapat berdiri dengan kokoh dan dapat digunakan secara aman. Tanah yang baik tidak memerlukan perlakuan khusus pada saat tanah tersebut digunakan sebagai pondasi suatu bangunan, namun tidak semua tanah memiliki sifat tanah yang baik yang mengakibatkan apabila dibangun suatu bangunan gedung, rumah, jalan, dan sebagainya bisa mengakibatkan terjadinya kerusakan pada konstruksi di atasnya. Kondisi tanah yang kurang baik terdapat di jalan SP 4 kelurahan Makbalim Distrik Mayamuk Kabupaten Sorong. Hal ini dapat terlihat dari kondisi jalan yang dibangun di daerah tersebut dengan mudah mengalami kerusakan seperti jalan berlubang dan bergelombang.

Perilaku tanah lempung, terutama kuat uji geser perlu diselidiki. Maka dengan itu upaya untuk memperbaiki sifat-sifat tanah asli agar memenuhi syarat serta mempunyai daya dukung yang cukup baik sebagai pondasi utuk dirikannya struktur diatas tanah tersebut dalam hal ini dilakukan dengan menggunakan campuran bubuk arang kayu. 
Pada uji kandungan unsur kimia bubuk arang kayu yang dilakukan di Laboratorium Kimia Analitik Jurusan Kimia Fakultas MIPA Universitas Gadjah Mada Yogyakarta, bubuk arang kayu mengandung unsur kimia yang terdiri dari karbon $(\mathrm{C})$, aluminium $(\mathrm{Al})$, silica $(\mathrm{Si})$, kalsium (Ca), magnesium $(\mathrm{Mg})$, dan fosfor $(\mathrm{P})$.

Dari latar belakang tersebut penulis menganggap perlu melakukan penelitian dengan judul "Stabilisasi Tanah Lempung Dengan Bubuk Arang Kayu Terhadap Kuat Geser"

\section{Tujuan Penelitian}

1. Untuk menganalisa karakteristik dari tanah asli Jalan SP 4 kelurahan Makbalim Distrik Mayamuk Kabupaten Sorong

2. Untuk menganalisa pengaruh pencampuran arang kayu pada tanah lempung terhadap kuat geser tanah.

\section{STATE OF THE ART}

Adapun penelitian terdahulu yang terkait dengan penelitian ini adalah sebagai berikut :

1. Menurut Sunarti Sagala (2014) mengatakan bahwa Bertambahnya kadar tanah lempung A7 pada campuran tanah pasir sungai menyebabkan peningkatan pada berat isi kering tanah, namu mengalami penurunan pada 30\% kadar lempung A-7. Kepadatan maksimum sebesar $1,815 \mathrm{~kg} / \mathrm{cm}^{3}$ pada kadar lempung A-7 $25 \%$ dan nilai kohesi maksimum didapat pada campuran $25 \%$ lempung A-7 yaitu $32,197 \mathrm{KPa}$. Nilai sudut geser dalam maksimum terdapat pada campuran $15 \%$ lempung A-7 sebesar $40,1^{\circ}$.

2. Menurut Zardi Muklis (2015) mengatakan bahwa Tanahlempung Desa Lampoh Keude termasuk ke dalam lempung anorganik dengan plastisitas tinggi yang disimbolkan dengan $\mathrm{CH}$ menurut system USCS dan termasuk golongan A-7-6 menurut system klasifikasi AASHTO dan Penambahan campuran semen dapat meningkatkan nilai $\varnothing$ dan c tanah lempung.

3. Menurut Bakri (2017) mengtakan bahwa Hasil uji CBR laboraratorium dengan variasi kadar abu batu sebesar 5\%,10\%, 15\%, 20\% dengan waktu pemeraman 48 jam dapat meningkatkan nilai CBR dari tanah asli dan dari hasil pengujian CBR laboratorium, pengaruh penambahan kadar abubatu sebesar 5\% mengalami peningkatan yang begitu tinggi di bandingkan variasi kadar campuran lainnya. Pengaruh penambahan abu batu sebesar 5\% dapat meningkatkan nilai CBR dari tanah asli sebesar $20.45 \%$ menjadi $42.72 \%$. maka dengan itu diketahui bahwa pencampuran tanah asli dengan kadar abu batu sebesar $5 \%$ adalah yang paling optimum.

\section{METODE}

\section{Tahapan Penelitian}

Tahapan penelitian yang digunakan adalah sebagai berikut :

1. Melakukan pengamatan langsung terhadap jalan SP 4 kelurahan Makbalim Distrik Mayamuk di wilayah Kabupaten Sorong.

2. Mengolah data dari hasil yang telah di dapatkan pada saat melakukan pengamatan langsung . 
3. Mengidentifikasi dan menganalisa permasalahan pada yang terjadi di muara sungai Kota Sorong.

Semua metode penulisan dan analisa dalam artikel ilmiah ini merujuk pada panduan penulisan tugas akhir Fakultas Teknik Universitas Muhammadiyah Sorong tahun 2014 (Pristianto, Amri, \& Rusdi, 2014).

\section{REFERENSI}

1. Sunarti Sagala (2014). Analisis Kuat Geser Langsung Tanah pada TPA Kudus.

2. Zardi Muklis (2015). Analisis Tanah lempung di Desa Lampoh Keude termasuk ke dalam lempung anorganik dengan plastisitas tinggi.

3. Bakri (2017). Peningkatan Nilai CBR Laboratorium Rendaman Tanah dengan Campuran Abu. 